\title{
Analysis of Tax Avoidance Effect on Firm Value (A Study on Firms Listed on Indonesia Stock Exchange)
}

\author{
Arfah Habib Saragih \\ Department of Fiscal Administrative Science, \\ Faculty of Administrative Science, Universitas Indonesia \\ Depok, Indonesia \\ arfah.habib11@ui.ac.id
}

\begin{abstract}
There are many factors that can affect firm value, including taxation. Taxes paid by firms to the government is a quite significant burden that firms often commit tax avoidance in order to minimize tax expense. The objective of this research is to examine the effect of tax avoidance committed by firms on the value of firms listed on Indonesia Stock Exchange in 2009-2016. The proxy for firm value in this research is Price to Book Value per Share (PBVS), while the proxy for tax avoidance is Effective Tax Rates (ETR). The final samples used in this study include 2,276 observations. From the result of fixed effect method unbalanced panel data regression, it can be concluded that tax avoidance, which is measured by effective tax rate, does not significantly affect firm value. This implies that 1 ) the sample firms do not use tax avoidance as an instrument to increase their firm value and 2) the investors no longer value the tax avoidance activities as an alternative to increase firm value since it has some risks that potentially will be faced by the firm in the future if there is an investigation executed by taxation authority. The firms should perform the other value-added activities to increase their firm value rather than tax avoidance activities.
\end{abstract}

Keywords: Tax Avoidance, Effective Tax Rates, Firm Value

\section{Introduction}

Tax is an inseparable element in life as a citizen and in the business world. In living under a state government, each citizen has a unique tax obligation that has been regulated by law, which is also the case with a firm. The taxes received from various parties will become state income which in turn will be used to fund state operations. As far as the government is concerned, tax is a state income. However, from a firm's perspective, tax is an expense which reduces firm profit. This prompts many firms to try to minimize tax payment to the government. In this case, agency problem emerges as revealed by Jensen and Meckling (1976). Conflict of interest subsequently occurs i.e. conflicts between firm management and the government, which is represented by the taxation authority. This conflict happens because firm management tries to minimize tax payment, whereas the government wants to maximize tax revenue received from firms. Desai and Dharmapala (2006) argued that tax avoidance related to agency tension that occurs is between the management and investors, which is called managerial opportunism or resource diversion, where tax avoidance transactions can provide facilities for management with opportunistic behavior, such as income manipulation, doing transactions with parties having special relationships, and diversion of resources. However, these are done whilst staying inside the corridor of tax law (tax avoidance) in order to avoid profit erosion by large amounts of taxes. Tax avoidance is an act done by the firm to explicitly reduce tax payment (Hanlon and Heitzman, 2010 and Lietz, 2014); reducing the effective tax rate of firm cash for a long period of time (Dyreng et al., 2008); and is a legal action to reduce the amount of tax owed (Barr et al., 1977). 
Since tax rates can be considered high, tax has an impact on many things. Each aspect of tax has a specific effect or influence on firm behavior, such as financing decision, investment decision, transaction, etc., which ultimately will affect the value of the firm itself. Firms will make various efforts to maximize their profits that will eventually maximize the firm value. In measuring firm value, Price to Book Value per Share (PBVS) ratio can be used i.e. comparing share price with the book value and divided by the number of shares issued. High PBVS value indicates high firm value. Many factors affect firm value, among others Corporate Social Responsibility (Jo and Harjoto, 2011), level of firm leverage (Jiang, 2004), growth and profitability (Varaiya et al, 1987; Cho and Pucik, 2005), and R\&D and dividends (Jannine, 2008). In addition, Wijaya and Wibawa (2010) also found that investment decision (measured by PER), financing decision (measured by DER), and dividend policy (measured by DPR) positively and significantly affect firm value. With regard to correlation between taxation element and firm value, several studies have also concluded some results, such as the increase of tax rates on firms reduces firm value (Doidge and Dyck, 2011) and firms with higher tax rates have higher firm value (Lisa et al, 2012).

Also, in order to maximize firm value, firms will be involved in tax management activities, especially tax avoidance. In order to spot or measure tax avoidance, Effective Tax Rates (ETR) can be used. ETR is frequently used by policy makers and relevant parties as a tool to identify firm taxation system because it provides trustworthy statistical summary of the cumulative effects of various tax incentives and firm tax rate changes (Kern and Morris, 1992; Gupita and Newberry, 1997 in Richardson and Lanis, 2007). ETR can be calculated as a value comparison between income tax expense and book income, or between income tax expense and operational cash flow (in Richardson and Lanis, 2007). ETR is what's actually imposed on the firm.

In its correlation with firm value, the higher the firm tax rate, the more tax paid by the firm to the government, which ultimately will reduce firm net profit. This reduced firm net profit may reduce firm value. Doidge and Dyck (2011) found that increase in tax rate on firms in Canada lowers firm value. This is consistent with what was stated by Lisa et al (2012) who found that firms with lower tax rates have higher firm value. Besides that, Chasbiandani and Martani (2012) in their research also stated that the lower the long term ETR paid by the firm, the firm value will be higher.

From several other studies, it is found that managers commit tax avoidance primarily to increase the wealth of the shareholders (improving firm value) (Wang, 2010). Chasbiandani and Martani (2012) found that long run tax avoidance has negative effect on firm value, while short run tax avoidance does not significantly affect firm value. Furthermore, they stated that it indicates that the lower the long term ETR paid by the firm, the higher the firm value. Meanwhile, Chen (2014) who studied tax avoidance and firm value in China found that tax avoidance has negative effect on firm value. On the other hand, the result of research conducted by Desai and Dharmapala (2009) found that tax avoidance activity has no effect on firm value because similar actions by the managers of poorlygoverned firms may be valued with more skepticism and lead to a zero or negative reaction by the investors. Desai and Dharmapala (2009) argued that for poorly-governed firms, increases in tax avoidance directly can add up after-tax firm value, but also generate higher opportunities for managers to divert income from shareholders.

Looking at the above research results, the author becomes interested in conducting a study entitled: "Analysis of Tax Avoidance Effect on Firm Value (A Study on Firms Listed on Indonesia Stock Exchange)". The author based this study on the previous ones, including the use of variables in the regression model (panel data), processed using Stata 12. The samples used are firms listed on in Indonesia Stock Exchange/Bursa Efek Indonesia (BEI) in the period of 2009-2016. The contribution provided by the result of this research is to add to the literature on the effect of firm tax avoidance on the value of firms in BEI in a fairly long period of time, namely from 2009 to 2016. This article also 
builds on the extensive literature in corporate finance on the determinants of firm value. This is expected to become a material for evaluation both for the government and the firms themselves in terms of tax management activities conducted by public firms in Indonesia. The result of this research can be used as a consideration in setting more reasonable and optimal tax rates in the future both from the perspectives of the government and the firms so that tax avoidance practices can be significantly reduced for better development of firms and the business world in Indonesia.

Based on the background description, the question raised in this research is how tax avoidance which is measured by effective tax rates affects the value of firms listed on Indonesia Stock Exchange during 2009-2016. The objective to be achieved in this research is to identify the effect of tax avoidance on the value of firms listed on Indonesia Stock Exchange during 2009-2016.

\section{Research Methodology}

\subsection{Development of Hypotheses}

This research aims to identify the effect of tax avoidance which is measured by effective tax rates on the value of firms listed on Indonesia Stock Exchange during 2009-2016. For this purpose, the author employs unbalanced panel data regression model which will be processed using fixed effect method using Stata 12 software. The model is built by first making and developing hypotheses as follows.

In its correlation with firm value, the higher the firm tax rates, the higher the tax paid by the firm to the government, ultimately lowering firm net profit. This reduced firm net profit may reduce firm value. Conversely, the lower the firm tax rates, the less tax will be paid by the firm to the government, which in turn may increase firm net profit, which is very likely to improve firm value from the perspectives of the investors. The tax rate paid to the government is referred to as ETR (effective tax rate). ETR can be measured by comparing tax expense to profit before tax. Lisa et al (2012) and Chasbiandani and Martani (2012) also concluded that firms with lower tax rates have higher firm value. Therefore, the hypotheses developed are:

H0: ETR has no effect on firm value

H1: ETR has negative and significant effect on firm value

\subsection{Population, Sample, and Research Data}

The population used in this research is all firms in Indonesia and the samples are taken from firms listed on Indonesia Stock Exchange in 2009-2016 by using purposive sampling method. The criteria required in this purposive sampling method are: 1) the company with the fiscal year December 31,2) do not have negative equity value, 3 ) do not suffer fiscal or accounting losses in order not to cause the value of ETR distorted (Richardson and Lanis, 2007), 4) have an ETR less than one value so as not to create problems in model estimation (Gupta and Newberry, 1997), and 5) have the required research data. The final samples used in this research include 2,276 observations. Research data is secondary data taken from Thomson Reuters Eikon and Financial Statement and Annual Report (www.idx.co.id).

\subsection{Research Methodology and Operationalization of Variables}

This research employs a panel data regression model with unbalanced data operated using fixed effect method that aims to identify the primary problem i.e. the effect of tax avoidance which is measured by ETR on firm value on Indonesia Stock Exchange during 2009-2016 by putting in control variables of firm size, firm profitability, and level of leverage. The model in this research is:

PBVS $_{\text {it }}=\alpha_{0}+\alpha_{1}$ ETR $_{\text {it }}+\alpha_{2}$ SIZE $_{\text {it }}+\alpha_{3}$ ROA $_{\text {it }}+$ $\alpha_{4} \mathrm{DER}_{\mathrm{it}}+\varepsilon_{\mathrm{it}}$

Remarks:

PBVS - Price to Book Value per Share

ETR - Effective Tax Rates (calculated by dividing income tax expense by pre-tax book income)

SIZE - Firm Size (calculated by total asset natural logarithm)

ROA - Return on Asset (calculated by dividing earnings before income tax by average total assets) DER - Debt to Equity Ratio (calculated by dividing 
total debts by total equity)

i - firm ordinal-i

$\mathrm{t}$ - year ordinal- $\mathrm{t}$

$\alpha_{0}$ - constant

$\alpha_{1}-\alpha_{4}$ - coefficient of each independent variable

$\varepsilon_{\text {it }}$ - error

\section{Research Result and Discussion}

In this section, the author will analyze and discuss the result of data processing to test the hypotheses that have been made, in order to accept or reject it. The author uses confidence levels of $90 \%, 95 \%$, and $99 \%$ (or $\alpha=10 \%, 5 \%$, and $1 \%$ ) to test the result and hypotheses.

\subsection{Descriptive Statistics Analysis}

Table 1 Descriptive Statistics Variables

\begin{tabular}{|c|c|c|c|c|c|}
\hline & PBVS & ETR & SIZE & ROA & DER \\
\hline Mean & 2.5489 & 0.2647 & 28.6728 & 0.0739 & 2.0497 \\
\hline Median & 1.3975 & 0.2511 & 28.5398 & 0.0507 & 1.1262 \\
\hline Min & 0.0128 & 0.0014 & 23.5351 & 0.0001 & 0.0087 \\
\hline Max & 88.3471 & 0.9936 & 34.5768 & 1.4402 & 33.0756 \\
\hline $\begin{array}{c}\text { Std. } \\
\text { Dev. }\end{array}$ & 4.6199 & 0.1512 & 1.8275 & 0.0879 & 2.5708 \\
\hline Obs. & 2.276 & 2.276 & 2.276 & 2.276 & 2.276 \\
\hline
\end{tabular}

PBVS dependent variable shows firm value which is the comparison between share price and book value divided by number of shares issued. The table above shows that the minimum value of PBVS is 0.0128 and the maximum value is 88.3471 with an average of 2.5489 . The average value, which is above zero, shows that most sample firms in this study have a share price higher than the book value. ETR independent variable shows the comparison between tax expense and profit before tax. The table above shows that the minimum value of ETR is 0.0014 and the maximum value is 0.9936 with an average of 0.2647 . The ETR average value of $26.47 \%$ shows that most sample firms in this study have an effective tax rate of $26.47 \%$. This value has exceeded the statutory tax rate in Indonesia, $25 \%$. It means that most firms used as sample in this research do not execute tax avoidance in aggressive way since it has average ETR more than $25 \%$.

The SIZE control variable is a firm measurement measured by total asset natural logarithm. The table above shows that the minimum value of SIZE is 23.5351 and the maximum value is 34.5768 with an average of 28.6728. Meanwhile, ROA which shows firm profitability has a minimum value of 0.0001 and a maximum value of 1.4402 with an average of 0.0739 (approximately $7 \%$ ). From this profitability ratio, the sample firms in this research in general can be considered quite profitable, since the average value of the profitability ratio is not negative. The last control variable, DER, shows the proportion of debt to total firm equity. The table above shows that the minimum value of DER is 0.0087 and the maximum value is 33.0756 with an average value of 2.0497 . The average value, which is above 1 , shows that most sample firms in this study get most of their financing from debt component rather than from share offering (equity).

\subsection{Analysis of the Effect of Tax Avoidance Measured by Effective Tax Rates on Firm Value}

This research uses unbalanced panel data regression processed using Stata 12. Based on the result of estimation method selection, the selected method is fixed effect method. Table 2 displays the result of the regression.

\subsubsection{Statistical Testing}

F-test. This statistical F-test is conducted to identify whether all independent variables together significantly influence the dependent variable or not. The regression result table above shows that the F-statistical value is 21.90 and the F-statistical probability is 0.0000 . This result shows that at confidence level of $99 \%(\alpha=1 \%)$, the independent variables (ETR, SIZE, ROA, DER) together has significant influence on the dependent variable (PBVS) of firm value.

Adjusted $\mathbf{R}^{\mathbf{2}}$ test. This test is conducted to identify how much independent variables can explain dependent variables in the examined equation/model. The table above shows that the Adjusted R-squared value is $9.53 \%$. This shows that 
$9.53 \%$ of the variations of firm value can be explained by the changes of ETR, SIZE, ROA, DER, whereas the remaining $90.47 \%$ is influenced by other factors outside of the model. This is very reasonable and very understandable because in reality there are indeed so many variables that can affect firm value, both micro variables and the even broader macro scope which is not included in this research model.

Table 2 Regression Result of the Effect of Tax Avoidance Measured by Effective Tax Rates on Firm Value

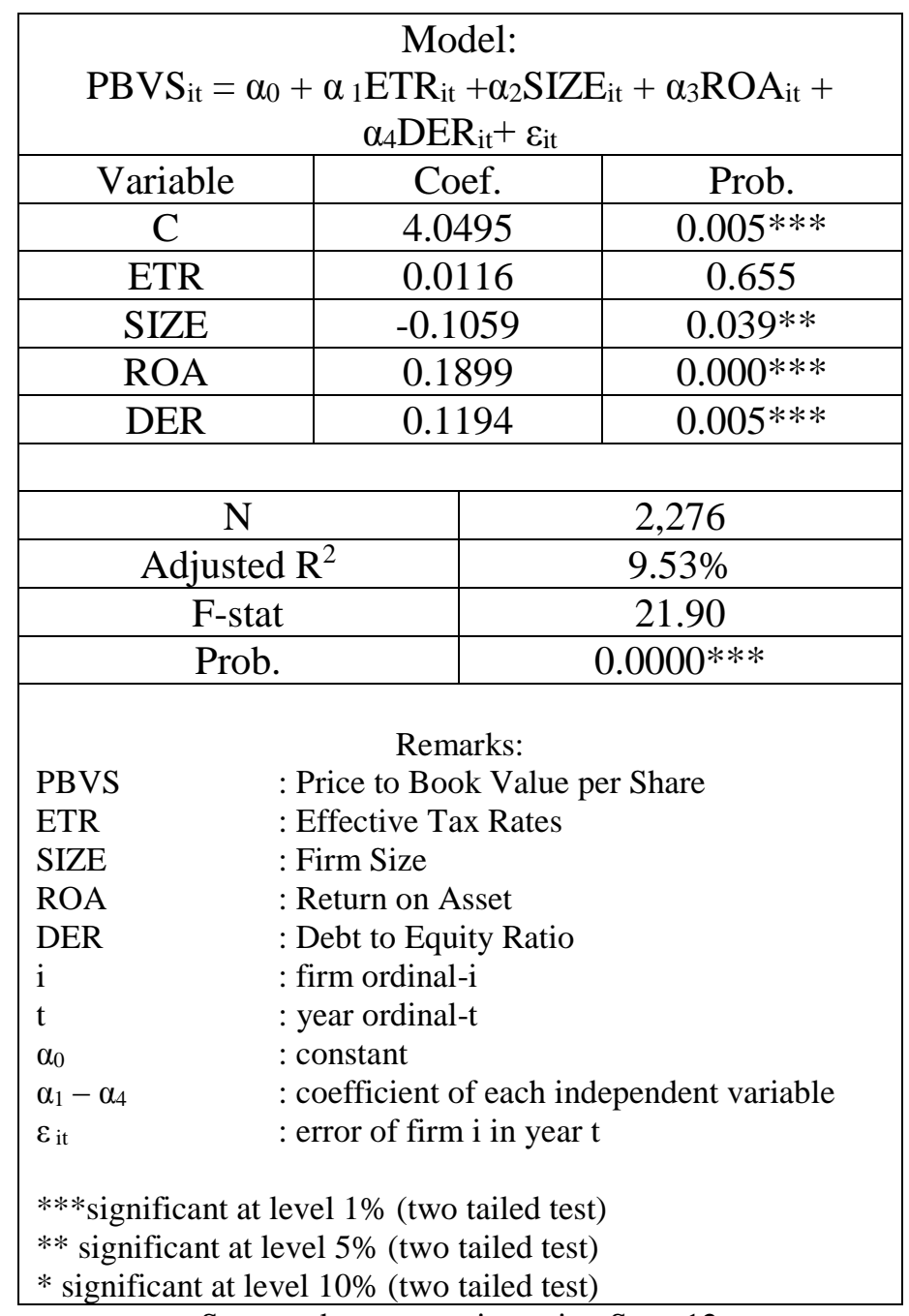

Source: data processing using Stata 12

t-test. This statistical t-test is conducted to identify the significance and amount of influence of independent variables on dependent variables assuming other independent variables are fixed/constant/ceteris paribus. Based on the regression result table above, it can be concluded that, at significance level of $99 \%(\alpha=1 \%)$ and $95 \%$ $(\alpha=5 \%)$, control variables ROA and DER and SIZE have significant influence on the firm value dependent variable (PBVS) respectively. This can be seen from $p$-value $<\alpha$. One independent variable, namely ETR, has no significant influence on the firm value dependent variable (PBVS).

\subsubsection{Analysis on Effective Tax Rate}

Table 2 above shows that at any significance level, ETR variable (with coefficient 0.0116 ) has p-value of 0.655 . This value is more than 0.05 therefore ETR variable is not located in $\mathrm{H} 0$ reject area, which means ETR is a variable that do not affect firm value. Thus, hypothesis H1 (ETR has negative and significant influence on firm value) is not proven. Tax avoidance which is measured by ETR has insignificant influence on firm value listed on Indonesia Stock Exchange during 2009-2016. This implies that, while the overall effect of tax avoidance on firm value is indifferent from zero. In this case, the sample firms do not use tax avoidance as an instrument to increase their firm value. They choose the safer way to increase their firm value by implementing all regulations required by the government especially by taxation authority. It is also proven by the average number of ETR about $26.47 \%$ which has exceeded the statutory tax rate in Indonesia, $25 \%$.

In this research, firm value is measured by PBVS (price compared to book value per share). This reflects investors' perception of the firm in terms of share price. Higher PBVS value shows higher investors' expectation of the firm in the future, persuading them to invest more than the firm's book value. In relation to tax avoidance, in this case investors do not view that tax avoidance activities will benefit the firm due to the low tax expense to be paid to the government. Insignificant influence of tax avoidance on firm value indicates that investors no longer value the tax avoidance activities as an alternative to increase firm value since it has some risks that potentially will be faced by the firm in the future if there is an investigation executed by taxation authority. This research result 
backs up the result of research conducted by Desai and Dharmapala (2009) that found that tax avoidance activity has no effect on firm value because similar actions by the managers of poorlygoverned firms may be valued with more skepticism and lead to a zero or negative reaction by the investors. Desai and Dharmapala (2009) argued that for poorly-governed firms, increases in tax avoidance directly can add up after-tax firm value, but also generate higher opportunities for managers to divert income from shareholders. This research result does not back up the result of research conducted by Chasbiandani and Martani (2012) that found that the lower the long-term ETR paid by the firm, the higher the firm value; Wang (2010) that concluded that firms commit tax avoidance primarily to increase the wealth of shareholders (increasing firm value); and Lisa et al (2012) that found that firms with lower tax rates have higher firm value.

This can be an input for the firms that the investors are no longer valuing tax avoidance as an instrument to increase the firm value. The firms should perform the other value-added activities to increase their firm value rather than tax avoidance. This also can be an input for the government in reviewing tax rate policies and corporate tax regulations in Indonesia and in monitoring tax avoidance activities/behaviors of firms in Indonesia so that the tax rates set can optimize government's tax revenue through reduction of firm tax avoidance activities. The government also needs to evaluate the effective tax rates imposed on firms in order to reduce the incentive to commit tax avoidance in the future.

\section{Conclusion}

This research aims to identify the effect of tax avoidance which is measured by effective tax rates on the value of firms listed on Indonesia Stock Exchange in 2009-2016. From the result of unbalanced panel data regression with fixed effect method conducted on 2,276 observations, it can be concluded tax avoidance which is measured by ETR has insignificant influence on firm value listed on Indonesia Stock Exchange during 2009-2016. This implies that, the sample firms do not use tax avoidance as an instrument to increase their firm value. Insignificant influence of tax avoidance on firm value indicates that investors no longer value the tax avoidance activities as an alternative to increase firm value since it has some risks that potentially will be faced by the firm in the future if there is an investigation executed by taxation authority. This research result backs up the result of research conducted by Desai and Dharmapala (2009) that found that tax avoidance activity has no effect on firm value because similar actions by the managers of poorly-governed firms may be valued with more skepticism and lead to a zero or negative reaction by the investors.

This can be an input for the firms in Indonesia, especially for those that listed on the Indonesia Stock Exchange, that the investors are no longer valuing tax avoidance as an instrument to increase the firm value. The firms should perform the other value-added activities to increase their firm value rather than tax avoidance activities.

\section{REFERENCES}

[1] Barr, N.A., James, S.R., \& Prest, A.R. (1977). Self-Assessment for Income Tax. London, Heinemann.

[2] Chasbiandani dan Martani (2012). Pengaruh Tax Avoidance Jangka Panjang terhadap Nilai Perusahaan. PPIA-FEUI.

[3] Chen, X., Hu, N., Wang, X., \& Tang, X. (2014). Tax avoidance and firm value: Evidence from china. Nankai Business Review International, 5(1), 25-42. doi:http://dx.doi.org/10.1108/NBRI-10-20130037.

[4] Cho, Hee-Jae and Pucik, Vladimir. (2005). Relationship between Innovativeness, Quality, Growth, Profitability, and Market Value. Strategic Management Journal. Vol. 26, No. 6 (Jun., 2005), pp. 555-575.

[5] Desai, M., and Dharmapala, D., (2006). Corporate tax avoidance and high-powered incentives. Journal of Financial Economics 79, 145-179.

[6] Desai, A.M., Dharmapala, D. (2009), Corporate tax avoidance and firm value. The Review of Economics and Statistics, 91(3), 537-546.

[7] Doidge, Craig and Dyck, Alexander. 2011. Taxes, Valuation, and Organizational Structure.

[8] Dyreng, S.D., Hanlon, M. and Maydew, E.L., (2008). Long-run Corporate Tax Avoidance, The Accounting Review,83(1), 61-82.

[9] Gupta, S., Newberry, K., (1997). Determinants of the variability in corporate effective tax rates: evidence from longitudinal study. Journal of Accounting and Public Policy, 1-34.

[10] Hanlon, Michelle. 2005. The Persistence and Pricing of Earnings, Accruals, and Cash Flows When firms Have Large Book-Tax Differences. The Accounting Review Vol. 80, No. 1, pp. 137-166.

[11] Jannine, P. H. (2008). R\&D and dividend payments as determinants of corporate value in the UK. International Journal of Managerial Finance, 4(1), 76-91.

[12] Jensen, Michael C. and Meckling, William H.. (1976). Theory of the firm: Managerial Behavior, Agency Costs, and Ownership Structure. 


\section{PRESS}

[17] Richardson, Grant. and Lanis, Roman. 2007. Determinants of the Variability in Corporate Effective Tax Rates and Tax Reform: Evidence from Australia. Journal of Accounting and Public Policy 26: 689-704.

Journal of Financial Economics, October, 1976, V. 3, No. 4, pp. $305-$ 360 .

[13] Jiang, Y. (2004). Taxes, debt, and firm value: New evidence. Yale University). ProQuest Dissertations and Theses, 186-186 p. Retrieved from http://search.proquest.com/docview/305117980?accountid=17242. (305117980).

[14] Jo, Hoje and Harjoto, Maretno A. 2011. Corporate Governance and firm Value: The Impact of Corporate Social Responsibility. Journal of Business Ethics 103: 351-383. Springer 2011.

[15] Lisa, A. B., David, A. G., \& Jackson, M. (2012). How do cross-country differences in corporate tax rates affect firm value? The Journal of the American Taxation Association, 34(2), 1-17,117.

[16] Lietz, G. (2014). Determinants and Consequences of Corporate Tax Avoidance. University of Munster: Institute of Accounting and Taxation.
[18] Varaiya, N., Roger, A. K., \& Weeks, D. (1987). The relationship between growth, profitability, and firm value. Strategic Management Journal (1986-1998), 8(5), 487-487.

[19] Wang, Xiaohang. (2010). Tax avoidance, corporate transparency, and firm value. Rochester, Rochester: doi: http://dx.doi.org/10.2139/ssrn.1716474.

[20] Wijaya, Lihan Rini Puspo dan Wibawa, Bandi Anas (2010). Pengaruh Keputusan Investasi, Keputusan Pendanaan, dan Kebijakan Dividen terhadap Nilai Perusahaan. Simposium Nasional Akuntansi XIII. 